\title{
Processes Governing Phosphorus Availability in Temperate Soils
}

\author{
E. Frossard, ${ }^{*}$ L. M. Condron, A. Oberson, S. Sinaj, and J. C. Fardeau
}

\begin{abstract}
Phosphorus losses from agricultural soil to water bodies are mainly related to the excessive accumulation of available $P$ in soil as a result of long-term inputs of fertilizer $P$. Since $P$ is a nonrenewable resource, there is a need to develop agricultural systems based on maximum $P$ use efficiency with minimal adverse environmental impacts. This requires detailed understanding of the processes that govern the availability of $P$ in soil, and this paper reviews recent advances in this field. The first part of the review is dedicated to the understanding of processes governing inorganic $P$ release from the solid phase to the soil solution and its measurement using two dynamic approaches: isotope exchange kinetics and desorption of inorganic $P$ with an infinite sink. The second part deals with biologically driven processes. Improved understanding of the abiotic and biotic processes involved in $P$ cycling and availability will be useful in the development of effective strategies to reduce $P$ losses from agricultural soils, which will include matching crop needs with soil $P$ release and the development of appropriate remediation techniques to reduce $P$ availability in high $\mathbf{P}$ status soils.
\end{abstract}

So ILs contain between 100 and $3000 \mathrm{mg} \mathrm{P} \mathrm{kg}^{-1}$ soil, most of which is present as orthophosphate compounds. The proportion of total soil $\mathrm{P}$ present in organic forms ranges from 30 to $65 \%$ (Harrison, 1987). The soil solution in agricultural soils, which is the main source of $P$ for plant roots, contains between 0.01 and $3.0 \mathrm{mg}$ $\mathrm{P} \mathrm{L}^{-1}$. The quantity of $\mathrm{P}$ present in the soil solution represents only a small fraction of plant needs, and the remainder must be obtained from the solid phase by a combination of abiotic and biotic processes. The pro-

E. Frossard, A. Oberson, and S. Sinaj, Group of Plant Nutrition, Inst. of Plant Sciences, Swiss Federal Institute of Technology (ETH Zürich), CH-8315 Eschikon-Lindau, Switzerland; L.M. Condron, Soil, Plant, and Ecological Sciences Div., P.O. Box 84, Lincoln Univ., Canterbury, New Zealand; and J.C. Fardeau, Soil Science, INRA, RD 10 (Route de Saint Cyr), F-78026 Versailles Cedex, France. Received 31 Aug. 1998. *Corresponding author (emmanuel.frossard@ipw.agrl. ethz.ch).

Published in J. Environ. Qual. 29:15-23 (2000). cesses involved in soil $\mathrm{P}$ transformation are precipitation-dissolution and adsorption-desorption which control the abiotic transfer of $P$ between the solid phase and soil solution, and biological immobilization-mineralization processes that control the transformations of $\mathrm{P}$ between inorganic and organic forms (Fig. 1).

Phosphorus losses from soils occur by leaching at very low rates in undisturbed ecosystems (Walker and Syers, 1976; St. Arnaud et al., 1988; Frossard et al., 1989; Letkeman et al., 1996). The implementation of intensive agricultural production has markedly increased $\mathrm{P}$ losses from soils through increased runoff, erosion and leaching, which in turn can have adverse effects on water quality. These losses are further increased by the excessive accumulation of bioavailable $P$ in the upper soil horizons, due either to application of inorganic and/or organic $\mathrm{P}$ fertilizers in excess of plant needs and/or to inappropriate fertilizer applications (Braun et al., 1994; Beaton et al., 1995; Sharpley et al., 1995; Sharpley and Rekolainen, 1997; Sibbesen and Runge-Metzger, 1995; Sibbesen and Sharpley, 1997; Daniel et al., 1998; van der Molen et al., 1998).

It is the hypothesis of this paper that an efficient way of reducing $\mathrm{P}$ losses to the environment while maintaining an optimum plant production is to combine limited but sufficient $\mathrm{P}$ inputs with maximum acquisition and utilization of soil and fertilizer $P$ by plants. Whereas traditional $\mathbf{P}$ fertilization strategies were designed to increase and maintain plant-available $\mathrm{P}$ in soil at levels required for maximum production (i.e., non-P limiting), it is now necessary to use soil and fertilizer $P$ resources more efficiently. Accordingly, there is a need to quantify not only the level of rapidly plant-available soil $\mathrm{P}$ but also the amount of $\mathrm{P}$, which can be released by desorp-

Abbreviations: DMT HFO, Pi extraction with a dialysis membrane tube filled with an hydrous ferric oxide; E1min, Pi isotopically exchangeable within 1 minute; E1min-12wk, Pi isotopically exchangeable between 1 minute and $12 \mathrm{wk}$; $\mathrm{E}>12 \mathrm{wk}$, Pi that cannot be exchanged within 12 wk; NMR, nuclear magnetic resonance. 


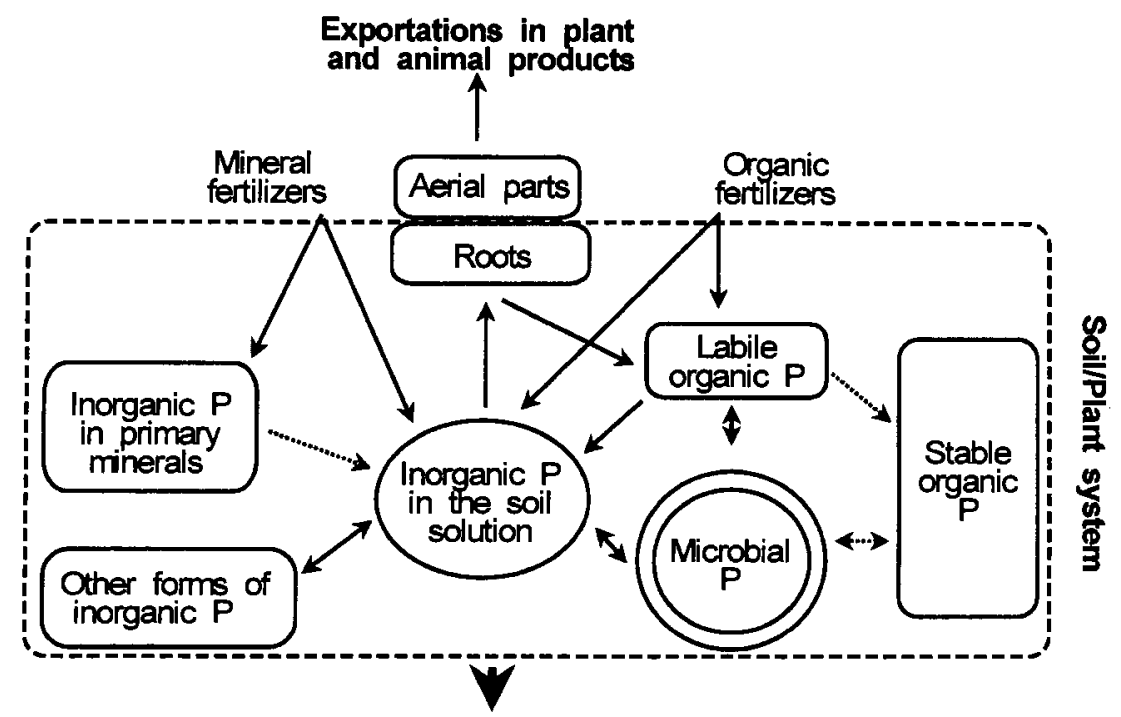

Fig. 1. The soil $P$ cycle (adapted from Stewart and McKercher, 1982).

tion over the season. In addition, it is also necessary to assess the influence of biological components (including microbial biomass, mycorrhiza, earthworms) on the acquisition, storage, and release of $P$ to plants. Finally, these various processes must be integrated to assist in the development of effective strategies to reduce risks associated with $P$ loss from high fertility soils.

Several review papers have been written on various aspects of soil P cycling (e.g., Stewart and Tiessen, 1987; Syers and Curtin, 1989; Frossard et al., 1995; Magid et al., 1996; Gressel and McColl, 1997). The aim of this paper is to review the more recent advances that have been made in understanding the abiotic and biotic processes that determine P availability in temperate soils. The extent to which these processes can be integrated at different levels of the soil-plant system to improve the efficiency of $\mathrm{P}$ utilization will also be considered, together with topics for future research.

\section{Abiotic Processes Controlling Inorganic Phosphorus Release to the Soil Solution}

The mechanisms underlying the short-term and longterm sorption of inorganic $\mathrm{P}(\mathrm{Pi})$ on pure minerals (carbonates and iron/aluminum oxides) and on soils are well documented (Parfitt, 1978; Barrow, 1983; Freese et al., 1995b; Scheinost and Schwertmann, 1995; Torrent, 1997). Much less attention has been paid to assessing the amount of $\mathrm{Pi}$ that can be potentially released from soils and soil minerals, although this is highly relevant, both in terms of plant nutrition and $\mathrm{P}$ losses. Recent studies have demonstrated that the amount of soil-available $\mathrm{Pi}$ and percentage of $\mathrm{Pi}$ saturation are related to concentrations of available $\mathrm{Pi}$ measured in runoff (Sharpley, 1995; Pote et al., 1996; Sibbesen and Sharpley, 1997) and leachates (Brookes et al., 1997).

Different methods can be used to assess the release of $\mathrm{Pi}$ to the soil solution. These include extraction with water (van der Pauw, 1971), dilute solutions of chemicals (Olsen et al., 1954; Cottenie et al., 1982; Ruiz et al., 1997), anion exchange resin (Sibbesen, 1978), isotopic exchange (Fardeau, 1996), and using an infinite sink such as the Fe oxide-impregnated paper (van der Zee et al., 1987).

Chemical extractants are of great interest because they are rapid and can be used for routine analysis. They must be used with caution because they dissolve variable proportions and forms of available and unavailable soil P (Fardeau et al., 1988; Kato et al., 1995; Tunney et al., 1997). The amount of $P$ extracted by anionic resins is well correlated to the $\mathrm{P}$ uptake by plants (Sibbesen, 1978; Tran et al., 1992). However, this method has also some drawbacks: (i) resins do not sorb-desorb specifically phosphate ions, (ii) in highly $\mathrm{P}$ fertile soils they are not able to act as an infinite sink for $\mathrm{Pi}$, and (iii) depending on the counter-ion used $\left(\mathrm{Cl}^{-}, \mathrm{F}^{-}, \mathrm{OH}^{-}\right.$, $\mathrm{CO}_{3}^{2-}$ ), resins might significantly alter the $\mathrm{pH}$ of the soil solution (Barrow and Shaw, 1977; Freese et al., 1995a). Therefore, the following sections will focus on two approaches:

1. Isotopic exchange, which measures the rate of $\mathrm{Pi}$ transfer between the solid phase and soil solution under steady state conditions

2. The infinite sink method, which measures the amount of Pi located on the solid phase which can migrate to the solution by maintaining a very low concentration of $\mathrm{Pi}$ in the soil solution

\section{Isotope Exchange Kinetics}

Since the use of isotope techniques to investigate $P$ cycling in soils has been recently reviewed (Fardeau, 1996; Di et al., 1997; Frossard and Sinaj, 1997), this section only focuses on the basic principles of the isotope exchange kinetic approach and highlights some recent results.

Numerous studies have shown that the main source of $P$ for most agricultural plants, in the presence or absence of mycorrhiza, is isotopically exchangeable $\mathbf{P i}$ (Larsen, 1967; Fardeau and Jappé, 1976; Bolan et al., 1984; Morel and Plenchette, 1994; Frossard et al., 1994). 
Fardeau et al. (1985) showed that studying the kinetics of isotopic exchange during a short experiment $(100$ $\min$ ) can be used to derive parameters for a model to predict the amount of Pi that will be exchangeable, and therefore available, over at least 3 mo (Fardeau et al., 1985; Frossard et al., 1994). This approach suggests that it is not possible to consider soil $\mathrm{Pi}$ as existing in discrete pools containing available and unavailable forms of $\mathrm{Pi}$. In contrast, the kinetic approach suggests that there is a continuum between forms of Pi that are immediately available, such as those present in the soil solution, and forms that are present on the solid phase and that are very slowly exchangeable, including adsorbed and precipitated forms of $\mathrm{Pi}$. This conclusion is consistent with previous studies on the kinetics of Pi sorption and desorption (Barrow, 1983; Lookman et al., 1995).

The isotope exchange kinetic approach takes into account the three parameters, which, according to Beckett and White (1964), are necessary to characterize soil Pi availability (i.e., intensity, quantity, and capacity factors) (Salcedo et al., 1991; Morel et al., 1994; Fardeau, 1996; Frossard and Sinaj, 1997). The intensity factor is provided by the concentration of $\mathrm{Pi}$ in the soil solution (Sinaj et al., 1998), the quantity factor is provided by the amount of isotopically exchangeable $\mathrm{Pi}[E(t)]$, and information on the capacity factor is provided by the rate of disappearance of radioactive Pi from the soil solution. Results from long-term field experiments show that isotopic exchange kinetics can accurately describe the response of crops to $\mathrm{P}$ fertilization in a wide range of soils, including Chernozems, Luvisols, Ultisols, and Oxisols (Oberson et al., 1993; Morel et al., 1994; Frossard and Sinaj, 1997; Oberson et al., 1999).

The isotope exchange technique has been used to assess $\mathrm{Pi}$ availability in large-scale studies in northeast France on sedimentary soils (Frossard et al., 1992) and in Albania on a wide range of soils developed mainly on sedimentary and metamorphic materials (Sinaj et al., 1992). Results from both studies demonstrated that the Pi buffering capacity of the soils, as determined by isotope exchange kinetics, was strongly related to the $\mathrm{Fe}$ and $\mathrm{Al}$ oxide content, and therefore could be predicted from soil parent material (Frossard et al., 1992, 1993; Sinaj et al., 1992). On the other hand, the quantity of isotopically exchangeable $\mathrm{Pi}$ measured during $1 \mathrm{~min}$ $\left(E_{1 \min }\right)$, which is considered to be totally and immediately plant available, is influenced by a combination of soil parameters and management.

Recently, Sinaj et al. (1997) showed that a large proportion of slowly exchangeable Pi becomes more rapidly exchangeable upon total soil dispersion (Table 1). Their results suggest that up to $30 \%$ of total soil $\mathrm{Pi}$ may be protected within water stable aggregates. This illustrates the importance of aggregation in determining the rate of release of Pi from the solid phase of soil particles, which can be organized in aggregates of various sizes, to the solution where roots take up $\mathrm{Pi}$ (Linquist et al., 1997).

\section{Infinite Sink Method}

The principle of this approach is to displace the $\mathrm{Pi}$ located on the solid phase of the soil by lowering Pi
Table 1. Comparison of isotopically exchangeable Pi measured on unfractionated soil samples sieved at $2 \mathrm{~mm}$ (UF) and calculated for the same samples after dispersion with a Na-resin (D) (adapted from Sinaj et al., 1997).

\begin{tabular}{|c|c|c|c|c|c|c|}
\hline \multirow[b]{2}{*}{ Soil } & \multicolumn{2}{|c|}{ E1min $\dagger$} & \multicolumn{2}{|c|}{ E1min-12wk $\neq$} & \multicolumn{2}{|c|}{$E>12 w k \S$} \\
\hline & UF & D & UF & D & UF & D \\
\hline & & & $-\mathbf{m}$ & $\mathbf{k g}^{-1}$ & & \\
\hline Uncultivated Calciustoll & 9.7 & 25.7 & 84.8 & 180.2 & 298 & 183 \\
\hline Cultivated Calciustoll & 3.6 & 5.1 & 8.9 & 22.4 & 227 & 196 \\
\hline Uncultivated Xeropsamment & 5.9 & 3.6 & 5.9 & 25.6 & 277 & 240 \\
\hline Cultivated Xeropsamment & 7.1 & 5.6 & 7.3 & 12.6 & 135 & 111 \\
\hline Uncultivated Haplosalid & 2.8 & 3.5 & $\mathbf{7 7 . 7}$ & 40.9 & 225 & 247 \\
\hline Cultivated Haplosalid & 6.8 & 3.6 & 9.6 & 34.0 & 297 & 261 \\
\hline Uncultivated Haplustert & $\mathbf{7 . 2}$ & 5.9 & 10.9 & 33.2 & 122 & 88 \\
\hline
\end{tabular}

$\dagger$ E1min: Pi isotopically exchangeable within $1 \mathrm{~min}$.

$\ddagger$ E1min-12wk: Pi isotopically exchangeable between $1 \mathrm{~min}$ and 12 wk.

$\S E>12$ wk: Pi that can not be exchanged within 12 wk.

concentration in the solution to a very low level, with minimal alteration of the system. This is done by shaking a soil water suspension with an Fe oxide-impregnated paper, which acts as a sink for Pi (van der Zee et al., 1987). The amount of $P$ extracted by this approach is closely related to the amount of soil $\mathrm{Pi}$ available to plants and the amount of sediment Pi available to algae (Chardon et al., 1996; Menon et al., 1997; Myers et al., 1997).

The major source of error encountered using the $\mathrm{Fe}$ oxide impregnated paper is the adhesion of small soil particles onto the paper, which can lead to a large overestimation of $\mathrm{P}$ availability (Perrott and Wise, 1993; Freese et al., 1995a; Myers et al., 1997). Furthermore, until now this method has been mostly used to measure the amount of $\mathrm{Pi}$, which could be extracted from the soil after a given time (usually $16 \mathrm{~h}$ ), and therefore it gives only an indication of the quantity factor. The few kinetics studies carried out have been mostly used to establish an appropriate extraction time, and results obtained in these studies were not evaluated in agronomic and environmental terms (van der Zee et al., 1987; Chardon et al., 1996; Myers et al., 1997).

Freese et al. (1995a) recently improved the paper method by using a dialysis membrane tube filled with a hydrous ferric oxide (DMT-HFO) as an infinite sink instead of $\mathrm{Fe}$ oxide-saturated paper. The use of the DMT-HFO technique slows down desorption of Pi from the soil, but prevents the adhesion of soil particles. In a further study, Lookman et al. (1995) used this technique to study the desorption kinetics of $\mathrm{Pi}$ from acidic sandy soils for $9.5 \mathrm{wk}$. Their results showed that $\mathrm{Pi}$ desorption could be described by a sum of exponential terms, and that even after 9.5 wk of desorption, significant amounts of Pi were still being desorbed (Fig. 2). These results suggest that most of the soil Pi could be desorbed over a sufficiently long period. Using the DMT-HFO technique, Lookman et al. (1995) also showed that the amount of rapidly desorbable Pi was closely related to the quantity of amorphous $\mathrm{Fe}$ and $\mathrm{Al}$ oxides and to their degree of saturation with $\mathrm{Pi}$.

Lookman et al. (1997) used solid state ${ }^{31} \mathrm{P}$ NMR to examine excessively fertilized acid sandy soils and observed the disappearance of a group of protonated ${ }^{31} \mathrm{P}$ nuclei (probably $\mathrm{Ca}-\mathrm{P}$ ) as a result of extraction with DMT-HFO (Fig. 3). Although they could not definitely 


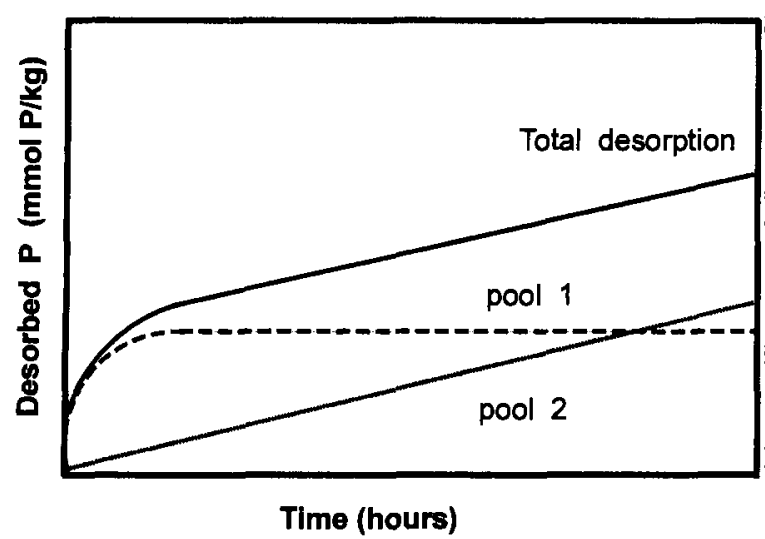

Fig. 2. Fitted curves for desorption of Pi from an excessively fertilized acid sandy soil using the HFO-DMT (hydrous ferric oxide-dialysis membrane tube) technique (adapted from Lookman et al., 1995). The curve total desorption shows the total amount of Pi desorbed from the soil. The curve pool 1 denotes the amount of Pi that can be desorbed from the pool containing rapidly desorbable $P i$. The curve pool 2 shows the amount of Pi that can be desorbed from the pool containing slowly desorbable $P i$.

assign their results to desorption or to the displacement of small particles, they showed on another sample that a sixfold water extraction led to a marked decrease in both $\mathrm{Ca}-\mathrm{P}$ and $\mathrm{Al}-\mathrm{P}$, and that no more $\mathrm{Pi}$ could be detected in the soil after oxalate extraction. The results obtained with the DMT-HFO technique and solid state NMR physically demonstrated the existence of several pools of $\mathrm{Pi}$ in soils: a pool containing $\mathrm{Pi}$ that is rapidly desorbed, a pool of slowly exchangeable $\mathrm{Pi}$, and a pool of $\mathrm{Pi}$ precipitated in condensed $\mathrm{Ca}$ phosphates (e.g., apatite) and/or strongly sorbed onto $\mathrm{Al}$ oxides.

Both the isotope exchange kinetics and infinite sink approaches allow precise characterization of the rate of $\mathrm{Pi}$ transfer between the solid phase and the soil solution.

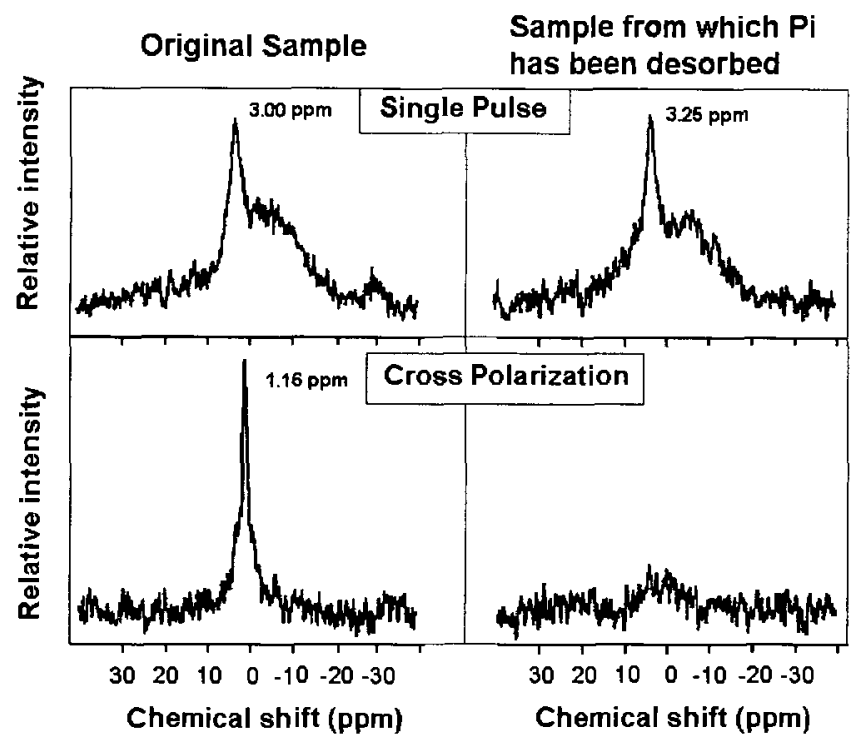

Fig. 3. Solid-state ${ }^{31} P$ MAS NMR (SP, single pulse; CP, cross polarization) of a particle-size fraction $(<50 \mu \mathrm{m})$ of an excessively fertilized acid sandy soil before and after desorption of labile $P i$ with the HFO-DMT (hydrous ferric oxide-dialysis membrane tube) technique (adapted from Lookman et al., 1997). The SP NMR experiment allows to observe all the ${ }^{31 P}$ nuclei in the soil, while the $C P$ NMR experiment shows selectively the ${ }^{31} P$ nuclei located within a few angstroms from ${ }^{1} \mathrm{H}$ nuclei.
Both approaches confirm the existence of a continuum of mobility between the Pi found in soil solution and Pi sorbed onto the solid phase, and that it is arbitrary to distinguish available and unavailable Pi fractions. Furthermore, these approaches allow measurement of the amount of Pi that can be released over the long term (e.g., during the time of intense uptake of nutrient by a crop). A comparison between these two approaches will enable the description of Pi fluxes between the soil's solid phase, soil solution, and plant roots during intense periods of Pi uptake. This information will have to be included in the development of soil fertility management schemes designed to optimize utilization of $\mathrm{Pi}$ inputs. However, to achieve this objective, the importance of soil micro- and macrostructure will have to be taken into account, and these Pi fluxes will have to be integrated with parameters that can be easily measured (e.g., soil tests, $\mathrm{P}$ inputs, qualitative and quantitative information on soil type).

\section{Biotic Processes Controlling Phosphorus Release to the Soil Solution}

The two main biotic processes that influence $\mathrm{Pi}$ release into soil solution are $P$ turnover through the microbial biomass and organic P mineralization. Despite extensive investigation, our understanding of organic $P$ dynamics in soil and the precise role of the soil microbial biomass is limited (Stewart and Tiessen, 1987; Magid et al., 1996). Nonetheless, in recent years significant advances have been made in the development and application of appropriate techniques to enable detailed examination of organic $\mathrm{P}$ components and biotic $\mathrm{P}$ dynamics in the soil environment.

A great deal of work has been focused on the separation and identification of different chemical forms of organic $\mathrm{P}$ in soil using detailed chemical fractionation and ${ }^{31} \mathrm{P}$ NMR spectroscopy. The application of both techniques to study soil organic $\mathrm{P}$ forms and dynamics has been recently reviewed (Sanyal and DeDatta, 1992; Magid et al., 1996; Preston, 1996; Condron et al., 1997).

Recent studies have confirmed that chemical fractionation of soil organic $\mathbf{P}$ based mainly on solubility in different alkali reagents (principally sodium bicarbonate $\left[\mathrm{NaHCO}_{3}\right]$ and sodium hydroxide $[\mathrm{NaOH}]$ ) is most useful in the examination of net long-term changes in organic $\mathbf{P}$ forms that occur in response to alterations in land use and/or soil management (e.g., Rubæk and Sibbesen, 1995; Condron et al., 1996; Oberson et al., 1996; Schmidt et al., 1996). Thus, in soils under $17 \mathrm{yr}$ of continuous cropping in the USA, Schmidt et al. (1996) showed that while $\mathrm{NaOH}$-extractable organic $\mathrm{P}$ increased in response to inputs of $\mathbf{P}$ fertilizer, organic $\mathbf{P}$ was released from this pool when $P$ fertilizer addition was discontinued. Condron et al. (1996) found that concentrations of total organic $P$ in topsoil $(0-10 \mathrm{~cm})$ decreased markedly (15-38\%) in the 10 to $31 \mathrm{yr}$ following the establishment of conifers in grassland soils in New Zealand. Most of the observed decreases in soil organic $\mathrm{P}$ under conifers occurred in the main $\mathrm{NaOH}$-extractable pool, with smaller, less consistent decreases in the $\mathrm{NaHCO}_{3}$ organic $\mathrm{P}$ pool. Oberson et al. (1996) found that levels of labile $\mathrm{NaHCO}_{3}$ and moderately labile 
$\mathrm{NaOH}$-extractable organic $\mathrm{P}$ were similar in adjacent soils under long-term organic (nutrients applied in organic manures) and conventional (nutrient applied in mineral and organic fertilizers) farming systems while the soils under conventional management consistently showed lower levels of biological activity (ATP content, enzyme activity). These findings reveal the restricted information obtained from extraction-based fractionation. Differences in soils over time show net changes only, and provide little information on the mechanisms responsible for soil organic $\mathbf{P}$ dynamics.

In short-term and seasonal studies of $\mathrm{P}$ dynamics, there has been some limited success in establishing relationships between soil organic $\mathrm{P}$ fractions and $\mathrm{P}$ availability. For example, Fabre et al. (1996) demonstrated that $\mathrm{NaHCO}_{3}$-extractable organic $\mathrm{P}$ increased during winter and decreased during summer. This finding is consistent with some earlier studies that indicated $\mathrm{NaHCO}_{3}$-extractable organic $\mathrm{P}$ represented a labile pool of organic $\mathrm{P}$ in temperate soils (Magid et al., 1996). It should also be noted that the nature of relationships between soil organic P fractions and exocellular phosphatase enzyme activities in soil remains unclear, and there is a need for continued detailed investigation of the precise role and functions of phosphatase enzymes in soil organic P dynamics (Magid et al., 1996; Gressel and McColl, 1997).

The validity of assigning relative availability to different chemical forms of soil organic $\mathrm{P}$ as defined by ease of extraction with reagents such as $\mathrm{NaHCO}_{3}$, especially over the short term, is uncertain and the need to define appropriate biologically meaningful pools of organic $\mathrm{P}$ in soil has been highlighted (Magid et al., 1996; Gressel and McColl, 1997). To this end, several recent studies have been concerned with the development of extraction techniques designed to better identify the labile pool of organic $\mathbf{P}$ in soil. For example, in a study conducted on an established field trial in Denmark, Rubæk and Sibbesen (1995) showed that organic P extracted from soil by a macroporous anion exchange resin (Lewatit MP500a) decreased in spring and was highest in summer, whereas $\mathrm{NaHCO}_{3}$-extractable organic $\mathrm{P}$ showed no distinct seasonal pattern.

In a related study, Guggenberger et al. (1996) examined the effects of land use (cropping, forestry, pasture) and $P$ fertilizer inputs on Lewatit MP500a resin-extractable organic P in soils from Germany and Denmark. They demonstrated that there was a close relationship between the resin-extractable organic $\mathrm{P}$ and labile diester forms of organic $\mathrm{P}$ determined in $\mathrm{NaOH}$ extracts using ${ }^{31} \mathrm{P}$ NMR (Fig. 4). This, together with the consistent $\mathrm{C} /$ organic $\mathrm{P}$ ratio of organic matter extracted from soil by the resin, indicated that the resin-extractable organic $\mathrm{P}$ represented a potentially labile pool, which they found increased under pasture and declined under arable cropping.

The findings presented by Guggenberger et al. (1996) suggest close links between organic $\mathrm{C}$ and organic $\mathrm{P}$ dynamics in soil. These links were demonstrated by Gressel et al. (1996) in litter-soil under a mixed conifer stand in California using a combination of solid-state ${ }^{13} \mathrm{C}$ NMR and liquid-state ${ }^{31} \mathrm{P}$ NMR. In a recent review,

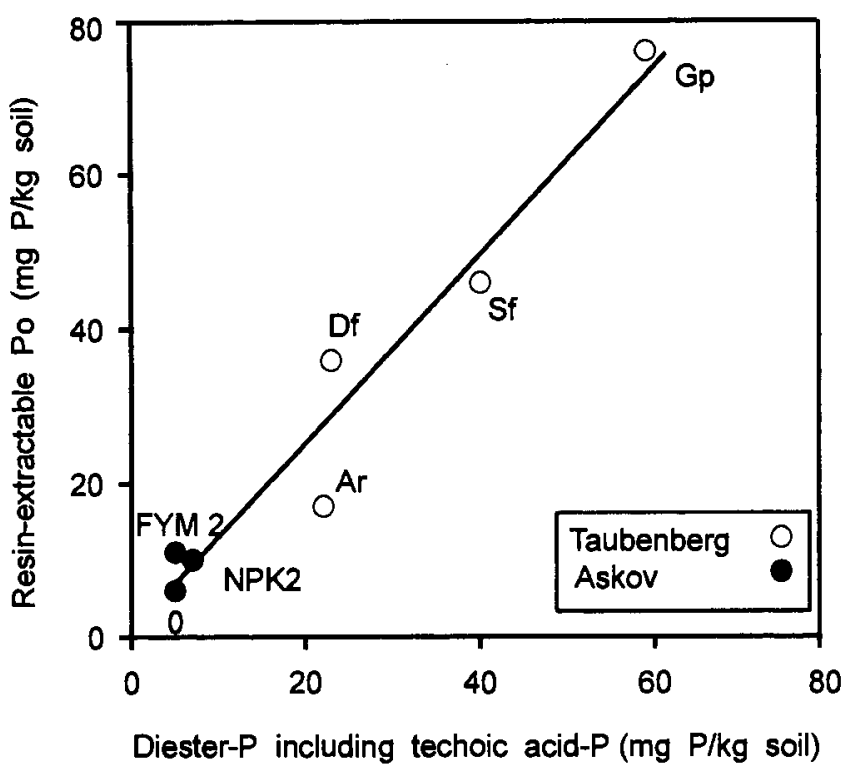

Fig. 4. Relationship between organic $P$ extracted by macroporous resin and diester organic $P$ (including techoic acid $P$ ) determined by ${ }^{31} P$ NMR in alkali extracts from selected German and Danish soils (adapted from Guggenberger et al., 1996).

Gressel and McColl (1997) concluded that continued advances in our understanding of organic $\mathbf{P}$ mineralization, particularly in forest soils and litter, will require an integrated approach involving consideration of $\mathrm{C}$ and organic $\mathrm{P}$ biochemistry and cycling.

The nature and dynamics of water-soluble organic $P$ and labile forms of soil organic $\mathrm{P}$ in the rhizosphere are undoubtedly linked to the activities of microflora and exocellular phosphatase enzymes (Joner et al., 1995; Gahoonia and Nielsen, 1995; Firsching and Claassen, 1996). Shand et al. (1994) showed that organic P exceeded $\mathrm{Pi}$ by 5 to 20 times in the soil solution from $\mathrm{P}$ deficient Cambisols. Pant et al. (1994) obtained soil solutions from various cropped soils and found that organic $\mathbf{P}$ accounted for up to $50 \%$ of the total $\mathrm{P}$. They also showed that 5 to $70 \%$ of the solution organic $P$ was hydrolyzed when incubated with phosphomonoesterase enzymes (phytase, acid, or alkaline phosphatase). Other studies have shown that plants grown in nutrient solutions can readily utilize water-soluble forms of organic $P$ after hydrolysis (e.g., Macklon et al., 1997). The continued development and refinement of appropriate techniques that enable detailed examination of rhizosphere processes (e.g., Zoysa et al., 1997; Gaume et al., 1998) will greatly assist in improving our understanding of organic $\mathbf{P}$ cycling and availability in soil.

The turnover or flux of $\mathrm{P}$ through the soil microbial biomass is widely acknowledged to be an important factor that determines the availability and utilization of organic $\mathrm{P}$ (and $\mathrm{Pi}$ ) in the soil-plant system (Stewart and Tiessen, 1987; Magid et al., 1996). Several recent studies have highlighted the importance of the microbial biomass in $\mathrm{P}$ cycling in temperate soils. Oberson et al. (1996) examined microbial P transformations in soil under contrasting farming systems in Switzerland. They concluded that both levels of microbial P (Fig. 5) and microbial $\mathbf{P}$ fluxes were greater under organic farming systems (based on inputs of organic manure) compared 
with a conventional farming system (based on inputs of mineral and organic fertilizers), and that they were important in relation to $\mathrm{P}$ uptake by plants. He et al. (1997) examined season changes in microbial biomass $P$ in pasture soils in a long-term trial in the UK. They found that microbial $\mathrm{P}$ levels and $\mathrm{P}$ concentration in the biomass as measured from its $\mathrm{C} / \mathrm{P}$ ratio were related to $\mathrm{P}$ inputs (mineral fertilizer or organic manure) and soil moisture. They calculated average microbial $P$ contents $(0-15 \mathrm{~cm})$ of 17 to $290 \mathrm{~kg} \mathrm{P} \mathrm{ha}^{-1}$, and estimated P fluxes through the soil microbial biomass of 11 to $190 \mathrm{~kg} \mathrm{P}$ $\mathrm{ha}^{-1} \mathrm{yr}^{-1}$, compared with $\mathrm{P}$ removed in herbage of only 2 to $11 \mathrm{~kg} \mathrm{P} \mathrm{ha}^{-1} \mathrm{yr}^{-1}$. In both studies, the $\mathrm{P}$ flux through the microbial biomass was deduced from temporal fluctuations in the microbial $\mathrm{P}$ content.

Brookes et al. (1984) calculated an annual $P$ flux through the microbial biomass by dividing microbial $P$ determined at one date by a turnover time of $2.5 \mathrm{yr}$. This turnover time had been calculated for biomass $\mathrm{C}$ by fitting a turnover model to data from field measurements made at Rothamsted (Jenkinson and Ladd, 1981). Both approaches represent estimates of the microbial P flux only, and direct measurement of flux has not been possible thus far. McLaughlin et al. (1988) successfully followed the incorporation of ${ }^{33} \mathrm{P}$-labeled plant tissue into soil microorganisms. Of the ${ }^{33} \mathrm{P}$ applied, 22 to $28 \%$ was recovered in the microbial biomass. This incorporation occurred within a short time after the addition of the labeled residues. However, most of the $\mathrm{P}$ taken up by the microbial biomass was derived from the soil.

Recent improvements in methodology to determine microbial P in soil (Morel et al., 1996) mean that there is scope for improved understanding of the role of the microbial biomass in organic $\mathrm{P}$ cycling and availability, especially when integrated with studies of Pi dynamics and $P$ uptake by plants. However, methods used so far to determine the amount of microbial $\mathbf{P}$ are based on chloroform fumigation and assess only a fraction of the

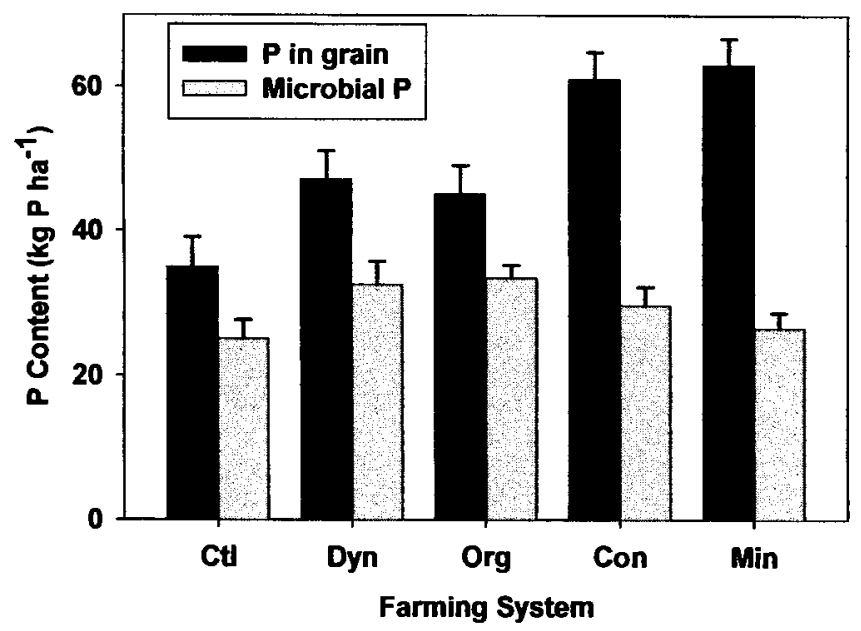

Fig. 5. Phosphorus content in grain and estimated $P$ content of the soil microbial biomass at the time of wheat (Triticum aestivum L.) harvest in soils after $14 \mathrm{yr}$ under different fertilization and cultivation regimes (Ctl, unfertilized; Dyn, bio-dynamic [exclusively organic fertilizers]; Org, bio-organic [organic fertilizers]; Con, conventional [mineral and organic fertilizers]; Min, conventional [exclusively mineral fertilizers]) (data from Oberson et al., 1993, 1996). total soil microbial P. The latter is calculated from chloroform released $\mathrm{P}$ using a correction factor, $k_{\mathrm{p}}$ (Brookes et al., 1982; Hedley and Stewart, 1982; McLaughlin et al., 1986). This factor can be determined by adding microorganisms to soil, either with known amounts of $\mathrm{P}$ (Brookes et al., 1982) or additionally ${ }^{33} \mathrm{P}$ labeled (Hedley and Stewart, 1982). The $k_{\mathrm{p}}$ factor should be determined for each soil, as microflora differ from soil to soil (McLaughlin et al., 1986). As added cultured populations of microorganisms are unlikely to represent the microbial population of a given soil, and added microorganisms are not physically protected by the soil, it might never be possible to measure the actual size of microbially bound $\mathrm{P}$, and it may be preferable to refrain from using the $k_{\mathrm{p}}$ factor at all.

It is recognized that the microbial biomass may take up $\mathrm{P}$ as a result of the addition of organic matter, or in response to changes in physiology caused by moisture fluctuations or other disturbances (McLaughlin et al., 1988; Tiessen et al., 1994b). The process of basal $\mathrm{N}$ mineralization using ${ }^{15} \mathrm{~N}$ (Mary and Recous, 1994) has not yet been applied to $P$. Such basal mineralization processes may occur at constant microbial $P$ compartment sizes. However, since the approaches used to assess microbial $P$ turnover mentioned above do not include this process, which could be closely linked to mineralization, this aspect should be explored.

As described previously, radioactive $\mathrm{P}$ isotopes can be successfully used to describe and determine the availability of $\mathrm{Pi}$ in soil. The principle of isotopic dilution was believed to be of limited value in determining organic $P$ mineralization due to problems associated with continued Pi sorption reactions (Di et al., 1997). However, recent studies have demonstrated that isotope exchange kinetics can be successfully used to determine gross organic $\mathbf{P}$ mineralization in soil. In theory, organic $\mathbf{P}$ mineralization can be calculated from the difference between isotopically exchangeable Pi measured after a given period of incubation and isotopically exchangeable Pi predicted for the same period from a shortterm $(100 \mathrm{~min})$ isotope exchange kinetics experiment conducted on the original (nonincubated) soil (Frossard and Sinaj, 1997; López-Hernández et al., 1998). Correct application of this methodology requires that the soil organic $\mathrm{P}$ is not labeled and the specific activity of $\mathrm{P}$ in solution is decreased by a combination of abiotic isotopic exchange and $\mathrm{P}$ released by mineralization (Frossard et al., 1996; López-Hernández et al., 1998). López-Hernández et al. (1998) used this technique to determine organic $\mathbf{P}$ mineralization in a number of low $\mathbf{P}$ fixing Mollisols from the USA and obtained mineralization rates of 220 to $900 \mu \mathrm{g} \mathrm{kg} \mathrm{k}^{-1} \mathrm{~d}^{-1}$. These findings indicate that there is considerable potential for the continued application and refinement of this technique to a wide range of soils.

\section{Integration of Abiotic and Biotic Processes to Minimize Phosphorus Loss from Soil to Water}

Besides decreasing the risk of $P$ transport from soil to water bodies by controlling erosion, runoff, and leaching as discussed in other papers in this series, $P$ losses 
from agricultural soils may be minimized by a combination of the following.

1. Reducing $P$ availability in excessively fertilized soils by lowering $P$ inputs and either increasing $P$ removal in produce or increasing the $P$ sorption capacity of soil. Data from long-term field experiments can be used to derive precise relationships between soil-available $P$ (e.g., water-soluble $\mathrm{Pi}$ ), $\mathrm{P}$ inputs, and $\mathrm{P}$ removal. These relationships have been shown to be closely related to the $\mathrm{P}$ buffering capacity of the soil, which in turn is related to soil mineralogy (clay, carbonates, $\mathrm{Fe} / \mathrm{Al}$ oxides). Accordingly, it should be possible to use these soil properties in combination with the plant requirements to predict the $\mathrm{P}$ input required to achieve optimum levels of water-soluble Pi.

During the last decade, several attempts have been made to decrease soil $P$ availability by applying amendments such as $\mathrm{Fe}$ oxides, alum, and coal combustion byproducts designed to increase the $\mathbf{P}$ sorption capacity of the soil (van der Molen et al., 1998, Shreve et al., 1996; Stout et al., 1998). Improved understanding of the $\mathbf{P}$ sorption-desorption properties of different soil amendments would be helpful in predicting decrease in $\mathrm{Pi}$ availability. Provided the $\mathrm{P}$ sorbing amendment is not an environmental risk and the complexed Pi remains very slowly available, this may be an appropriate strategy to reduce available $P$ in high-fertility soils, especially in combination with efforts to increase $\mathrm{P}$ removal in produce.

2. Modify cropping systems to achieve optimum utilization of soil and fertilizer $P$. Phosphorus is a vital nonrenewable resource. In addition to establishing upper limits of soil-available $P$ to minimize $P$ losses in runoff and drainage (Sibbesen and Sharpley, 1997), it is necessary to develop cropping systems that use soil P efficiently. The development of $\mathrm{P}$ efficient cropping systems in temperate ecosystems will require the following:

- The overall balance of $P$ in the soil-plant-animal system must be accurately quantified (e.g., Nguyen and Goh, 1992; Yanai, 1992; Zaccheo et al., 1997);

- The long-term release of soil Pi must be understood and monitored;

- Soil biotic processes (micro- and macrofauna, including endomycorrhiza) must be optimized to maintain $\mathrm{P}$, either in the living biomass or in easily degradable forms of soil organic matter (e.g., particulate organic matter);

- Plant breeding and selection to obtain species that are most efficient at extracting soil $\mathrm{P}$, even at low soil $P$ levels;

- Rotational cropping systems that include P-efficient crops should be employed where possible;

- Appropriate measures to protect and maintain soil and water resources should be included (e.g., use of riparian buffer zones between cultivated land and water bodies).

\section{Research Priorities}

Our ability to develop and implement effective integrated strategies for the efficient use of soil and fertilizer $\vec{P}$ is hampered by deficiencies in our understanding of key processes that control $\mathbf{P}$ cycling and availability in soil. To this end, future research in the area of soil $\mathrm{P}$ cycling should focus on the following:

- Measurement of rates of abiotic Pi release from solid phase to soil solution, especially over the long term;

- Continued development and refinement of techniques to measure soil organic $\mathbf{P}$ mineralization and $\mathbf{P}$ turnover through the soil microbial biomass and their temporal relationship to plant needs;

- Establish and quantify relationships between land use and biological soil $\mathbf{P}$ transformations (including the role of endomycorrhizae);

- Identify crop plant species with high $\mathrm{P}$ acquisition efficiency including at low soil $P$ levels;

- Continued development and evaluation of mechanistic models of soil $\mathrm{P}$ cycling that integrate abiotic and biotic processes (e.g., Tiessen et al., 1994a; Grant and Heaney, 1997), including consideration of spatial variability and soil characteristics at field level.

Finally, it should be stressed that effective results can only be obtained if the above research is conducted in an integrated manner since it requires input from a number of specialists.

\section{ACKNOWLEDGMENTS}

Attendance at the Organization for Economic Cooperation and Development (OECD) Workshop on "Practical and Innovative Means for the Control of Agricultural Phosphorus Losses to Water" (Belfast, June 1998) was possible thanks to funds provided by the OECD (EF) and the Commonwealth Science Council (LMC).

\section{REFERENCES}

Barrow, N.J. 1983. A mechanistic model for describing the sorption and desorption of phosphate by soil. J. Soil Sci. 34:733-750.

Barrow, N.J., and T.C. Shaw. 1977. Factors affecting the amount of phosphate extracted from soil by anion exchange resin. Geoderma 18:309-323.

Beaton, J.D., T.L. Roberts, E.H. Halstead, and L.E. Colwell. 1995. Global transfers of $\mathrm{P}$ in fertilizer materials and agricultural commodities. p. 7-26. In H. Tiessen (ed.) Phosphorus cycling in terrestrial and aquatic ecosystems: A global perspective. John Wiley, New York

Beckett, P.H.T., and R.E. White. 1964. Studies on the phosphate potential of soils: III. The pool of labile inorganic phosphate. Plant Soil 21:253-282.

Bolan, N.S., A.D. Robson, N.J. Barrow, and L.A.G. Aylmore. 1984. Specific activity of phosphorus in mycorrhizal and nonmycorrhizal plants in relation to the availability of phosphorus to plants. Soil Biol. Biochem. 16:299-304.

Braun, M., P. Hurni, and E. Spiess. 1994. Phosphor- und Stickstoffüberschüsse in der Landwirtschaft und Para-Landwirtschaft (Book in German with English abstract). Schriftenreihe der FAC nummer 18. Eidgenössische Forschungsanstalt für Agrikulturchemie und Umwelthygiene, Bern, Switzerland.

Brookes, P.C., G. Heckrath, J. De Smet, G. Hofman, and J. Vanderleen. 1997. Losses of phosphorus in drainage water. p. 253-272. In H. Tunney et al. (ed.) Phosphorus loss from soil to water. CAB International, Wallingford, UK.

Brookes, P.C., D.S. Powlson, and D.S. Jenkinson. 1982. Measurement of microbial biomass phosphorus in soil. Soil Biol. Biochem. 14:319-329.

Brookes, P.C., D.S. Powlson, and D.S. Jenkinson. 1984. Phosphorus in the soil microbial biomass. Soil Biol. Biochem. 16:169-175.

Chardon, W.J., R.G. Menon, and S.H. Chien. 1996. Iron oxide impregnated filter paper (Pi test): A review of its development and methodological research. Nutr. Cycl. Agroecosyst. 46:41-51.

Condron, L.M., M.R. Davis, R.H. Newman, and I.S. Cornforth. 1996. 
Influence of conifers on the forms of phosphorus in selected New Zealand grassland soils. Biol. Fertil. Soils 21:37-42.

Condron, L.M., E. Frossard, R.H. Newman, P. Tekely, and J.L. Morel. 1997. Use of ${ }^{31} \mathrm{P}$ NMR in the study of soils and the environment. p. 247-276. In M.A. Nanny et al. (ed.) Nuclear magnetic resonance spectroscopy in environmental chemistry. Oxford Univ. Press, New York.

Cottenie, A., M. Verlod, L. Kiekens, and R. Camerlynck. 1982. Chemical analysis of plant and soils. Laboratory of Analytical and Agrochemistry, State Univ., Ghent, Belgium.

Daniel, T.C., A.N. Sharpley, and J.L. Lemunyon. 1998. Agricultural phosphorus and eutrophication: A symposium overview. J. Environ. Qual. 27:251-257.

Di, H.J., L.M. Condron, and E. Frossard. 1997. Isotope techniques to study phosphorus cycling in agricultural and forest soils: A review. Biol. Fertil. Soils 24:1-12.

Fabre, A., G. Pinay, and C. Ruffinoni. 1996. Seasonal changes in inorganic and organic phosphorus in the soil of a riparian forest. Biogeochem. 35:419-432.

Fardeau, J.C. 1996. Dynamics of phosphate in soils. An isotopic outlook. Fert. Res. 45:91-100.

Fardeau, J.C., and J. Jappé. 1976. Nouvelle méthode de détermination du phosphore assimilable par les plantes: Extrapolation des cinétiques de dilution isotopique. (In French, with English abstract) C.R. Séances Acad. Sci. (Paris) t. 282, Série D :1137-1140.

Fardeau, J.C., C. Morel, and R. Boniface. 1988. Pourquoi choisir la méthode Olsen pour estimer le phosphore "assimilable" des sols? (In French, with English abstract) Agronomie (Paris) 8:577-584.

Fardeau, J.C., C. Morel, and J. Jappé. 1985. Cinétique d'échange des ions phosphate dans les systèmes sol:solution. Vérification expérimentale de l'équation théorique. (In French, with English abstract) C.R. Séances Acad. Sci. (Paris) t. 300, III $8: 371-376$.

Firsching, B.M., and N. Claassen. 1996. Root phosphatase activity and soil organic phosphorus utilization by Norway spruce (Picea abies (L.) Karst.). Soil Biol. Biochem. 28:1417-1424.

Freese, D., R. Lookman, R. Merckx, and W.H. van Riemsdijk. 1995a. New method for the assessment of long-term phosphate desorption from soils. Soil Sci. Soc. Am. J. 59:1295-1300.

Freese, D., W.H. van Riemsdijk, and S.E.A.T.M. van der Zee. 1995b. Modelling phosphate sorption kinetics in acid soils. Eur. J. Soil Sci. 46:239-245.

Frossard, E., M. Brossard, M.J. Hedley, and A. Metherell. 1995. Reactions controlling the cycling of $\mathrm{P}$ in soils. p. 107-137. In H. Tiessen (ed.) Phosphorus cycling in terrestrial and aquatic ecosystems: A global perspective. John Wiley, New York.

Frossard, E., J.C. Fardeau, M. Brossard, and J.L. Morel. 1994. Soil isotopically exchangeable phosphorus: A comparison between E and L values. Soil Sci. Soc. Am. J. 58:846-851.

Frossard, E., J.C. Fardeau, M. Ognalaga, and J.L. Morel. 1992. Influences of agricultural practices, soil properties and parent material on the phosphate buffering capacity of cultivated soils developed in temperate climates. Eur. J. Agron. 1:45-50.

Frossard, E., C. Feller, H. Tiessen, J.W.B. Stewart, J.C. Fardeau, and J.L. Morel. 1993. Can an isotopic method allow for the determination of the phosphate fixing capacity of soils? Commun. Soil Sci. Plant Anal. 24:367-377.

Frossard, E., D. López-Hernández, and M. Brossard. 1996. Can isotopic exchange give valuable information on the rate of organic phosphorus in soils? Soil Biol. Biochem. 28:857-854.

Frossard, E., and S. Sinaj. 1997. The isotope exchange kinetic technique: $\mathrm{A}$ method to describe the availability of inorganic nutrients. Applications to $\mathrm{K}, \mathrm{PO}_{4}, \mathrm{SO}_{4}$ and $\mathrm{Zn}$. Isot. Environ. Health Stud. 33:61-77.

Frossard, E., J.W.B. Stewart, and R.J. St. Arnaud. 1989. Distribution and mobility of phosphorus in grassland and forest soils of Saskatchewan. Can. J. Soil Sci. 69:401-416.

Gahoonia, T.S., and N.E. Nielsen. 1995. Phosphorus mobilization in the rhizosphere as influenced by plant-soil interactions. p. 208-216. In H.F. Cook (ed.) Soil management in sustainable agriculture. Wye College Press, Ashford, UK.

Gaume, A., E. Frossard, and F. Mächler. 1998. Influence of organic acids mucilage exuded by the roots of Zea mays L. on P bioavailability. Pap. 323 on CD-ROM. In Proc. of the 16th World Congr. of Soil Science, Montpellier, France. 20-26 Aug. 1998. ISSS, AFES, CIRAD, Montpellier, France.
Grant, R.F., and D.J. Heaney. 1997. Inorganic phosphorus transformation and transport in soils: Mathematical modeling in ecosys. Soil Sci. Soc. Am. J. 61:752-764.

Gressel, N., and J.G. McColl. 1997. Phosphorus mineralization and organic matter decomposition: A critical review. p. 297-309. In G. Cadisch and K.E. Giller (ed.) Driven by nature: Plant litter quality and decomposition. CAB International, Wallingford, UK.

Gressel, N., J.G. McColl, C.M. Preston, R.H. Newman, and R.F. Powers. 1996. Linkages between phosphorus transformations and carbon decomposition in a forest soil. Biogeochem. 33:97-123.

Guggenberger, G., B.T. Christensen, G. Rubak, and W. Zech. 1996. Land-use and fertilization effects on P forms in two European soils: resin extraction and 31P-NMR analysis. Eur. J. Soil Sci. 47:605-614.

Harrison, A.F. 1987. Soil organic phosphorus: A review of world literature. CAB International, Wallingford, UK.

He, Z.L., J. Wu, A.G. O'Donnell, and J.K. Syers. 1997. Seasonal responses in microbial biomass carbon, phosphorus, and sulphur in soils under pasture. Biol. Fert. Soils 24:421-428.

Hedley, M.J., and J.W.B. Stewart. 1982. Method to measure microbial phosphate in soils. Soil Biol. Biochem. 14:377-385.

Jenkinson, D.S., and J.N. Ladd. 1981. Microbial biomass in soil: measurement and turnover. p. 415-471. In E.A. Paul and J.N. Ladd (ed.) Soil biochemistry. Vol. 5. Marcel-Dekker, New York.

Joner, E.J., J. Magid, T.S. Gahoonia, and I. Jakobsen. 1995. P depletion and activity of phosphatases in the rhizosphere of mycorrhizal and non-mycorrhizal cucumber (Cucumis sativus L.). Soil Biol. Biochem. 27:1145-1151.

Kato, N., F. Zapata, and J.C. Fardeau. 1995. The ability of chemical extraction methods to estimate plant-available soil $\mathrm{P}$ and a better understanding of $\mathrm{P}$ availability of fertilized andosols by using isotopic methods. Soil Sci. Plant Nutr. 41:781-789.

Larsen, S. 1967. Soil phosphorus. Adv. Agron. 19:151-210.

Letkeman, L.P., H. Tiessen, and C.A. Campbell. 1996. Phosphorus transformations and redistribution during pedogenesis of western Canadian soils. Geoderma 71:201-218.

Linquist, B.A., P.W. Singleton, R.S. Yost, and K.G. Cassman. 1997. Aggregate size effects on the sorption and release of phosphorus in an ultisol. Soil Sci. Soc. Am. J. 61:160-166.

Lookman, R., D. Freese, R. Merckx, K. Vlassak, and W.H. van Riemsdijk. 1995. Long term kinetics of phosphate release in soils. Environ. Sci. Technol. 29:1569-1575.

Lookman, R., P. Grobet, R. Merckx, and W.H. van Riemsdjik. 1997. Applications of ${ }^{31} \mathrm{P}$ and ${ }^{27} \mathrm{Al}$ MAS NMR for phosphate speciation studies in soil and aluminium hydroxydes: Promises and constraints. Geoderma 80:369-388.

López-Hernández, D., M. Brossard, and E. Frossard. 1998. P-isotopic exchangeable values in relation to Po mineralization in soils with very low P-sorbing capacities. Soil Biol. Biochem. 30:1663-1670.

Macklon, A.E.S., S.J. Grayston, C.A. Shand, A. Sim, S. Sellars, and B.G. Ord. 1997. Uptake and transport of phosphorus by Agrostis capillaris seedlings from rapidly hydrolysed organic sources extracted from ${ }^{32} \mathrm{P}$-labelled bacterial cultures. Plant Soil 190:163-167.

Magid, J., H. Tiessen, and L.M. Condron. 1996. Dynamics of organic phosphorus in soils under natural and agricultural ecosystems. p. 429-466. In A. Piccolo (ed.) Humic substances in terrestrial ecosystems. Elsevier, Amsterdam, the Netherlands.

Mary, B., and S. Recous. 1994. Measurement of nitrogen mineralization and immobilization fluxes in soil as a means of predicting net mineralization. Eur. J. Agron. 3:291-300.

McLaughlin, M.J., A.M. Alston, and J.K. Martin. 1986. Measurement of phosphorus in the soil microbial biomass: A modified procedure for field soils. Soil Biol. Biochem. 18:437-443.

McLaughlin, M.J., A.M. Alston, and J.K. Martin. 1988. Phosphorus cycling in wheat-pasture rotations: II. The role of the microbial biomass in phosphorus cycling. Aust. J. Soil Res. 26:333-342.

Menon, R.G., S.H. Chien, and W.J. Chardon. 1997. Iron oxideimpregnated filter paper (Pi-test): II. A review of its application. Nutr. Cycl. Agroecosyst. 47:7-18.

Morel, C., and C. Plenchette. 1994. Is the isotopically exchangeable phosphate of a loamy soil the plant-available P? Plant Soil 158:287-297.

Morel, C., H. Tiessen, J.O. Moir, and J.W.B. Stewart. 1994. Phosphorus transformations and availability under cropping and fertilization assessed by isotopic exchange. Soil Sci. Soc. Am. J. 58: $1439-1445$. 
Morel, C., H. Tiessen, and J.W.B. Stewart. 1996. Correction for P-sorption in the measurement of soil microbial biomass $\mathrm{P}$ by $\mathrm{CHCl}_{3}$ fumigation. Soil Biol. Biochem. 28:1699-1706.

Myers, R.G., G.M. Pierzynski, and S.J. Thien. 1997. Iron oxide sink method for extracting soil phosphorus: paper preparation and use. Soil Sci. Soc. Am. J. 61:1400-1407.

Nguyen, M.L., and K.M. Goh. 1992. Nutrient cycling and losses based on a mass-balance model in grazed pasture receiving long-term superphosphate applications in New Zealand: I. Phosphorus. J. Agric. Sci. (Camb.) 119:89-106.

Oberson, A., J.M. Besson, N. Maire, and H. Sticher. 1996. Microbiological processes in soil organic phosphorus transformations in conventional and biological cropping systems. Biol. Fertil. Soils 21:138-148.

Oberson, A., J.C. Fardeau, J.M. Besson, and H. Sticher. 1993. Soil phosphorus dynamics in cropping systems managed according to conventional and biological agricultural methods. Biol. Fertil. Soils 16:111-117.

Oberson, A., D.K. Friesen, H. Tiessen, C. Morel, and W. Stahel. 1999. Phosphorus status and cycling in native savanna and improved pastures on a low-P Colombian oxisol. Nutr. Cycl. Agrosyst. 55:77-88.

Olsen, S.R., C.V. Cole, F.S. Watanabe, and L.A. Dean. 1954. Estimation of available phosphorus in soils by extraction with sodium bicarbonate. USDA Circ. 939. U.S. Gov. Print. Office, Washington, DC.

Pant, H.K., A.C. Edwards, and D. Vaughan. 1994. Extraction, molecular fractionation and enzyme degradation of organically associated phosphorus in soil solutions. Biol. Fertil. Soils 7:196-200.

Parfitt, R.L. 1978. Anion adsorption by soils and soil material. Adv. Agron. 30:1-50.

Perrott, K.W., and R.G. Wise. 1993. An evaluation of some aspects of the iron oxide-impregnated filter paper $(\mathrm{Pi})$ test for available soil phosphorus with New Zealand soils. N.Z. J. Agric. Res. 36:157-162.

Pote, D.H., T.C. Daniel, A.N. Sharpley, P.A. Moore, Jr., D.R. Edwards, and D.J. Nichols. 1996. Relating extractable soil phosphorus to phosphorus losses in runoff. Soil Sci. Soc. Am. J. 60:855-859.

Preston, C.M. 1996. Applications of NMR to soil organic matter analysis: History and perspectives. Soil Sci. 16I:144-166.

Rubæk, G., and E. Sibbesen. 1995. Soil phosphorus dynamics in a long-term field experiment at Askov. Biol. Fertil. Soils 20:86-92.

Ruiz, J.M., A. Delgado, and J. Torrent. 1997. Iron-related phosphorus in overfertilized European soils. J. Environ. Qual. 26:1548-1554.

Salcedo, I.H., F. Bertino, and E.S.V.B. Sampaio. 1991. Reactivity of phosphorus in northeastern Brazilian soils assessed by isotopic dilution. Soil Sci. Soc. Am. J. 55:140-145.

Sanyal, S.K., and S.K. DeDatta. 1992. Chemistry of phosphorus transformations in soil. Adv. Soil Sci. 16:1-120.

Scheinost, A.C., and U. Schwertmann. 1995. Predicting phosphate adsorption-desorption in a soilscape. Soil Sci. Soc. Am. J. 59: 1575-1580.

Schmidt, J.P., S.W. Buol, and E.J. Kamprath. 1996. Soil phosphorus dynamics during seventeen years of continuous cultivation: Fractionation analyses. Soil Sci. Soc. Am. J. 60:1168-1172.

Shand, C.A., A.E.S. Macklon, A.C. Edwards, and S. Smith. 1994. Inorganic and organic $\mathrm{P}$ in soil solutions from three upland soils: I. Effect of soil solution extraction conditions, soil type and season. Plant Soil 159:255-264.

Sharpley, A.N. 1995. Dependence of runoff phosphorus on soil phosphorus. J. Environ. Qual. 24:920-926.

Sharpley, A.N., M.J. Hedley, E. Sibbesen, A. Hillbricht-Ilkowska, W.A. House, and L. Ryszkowski. 1995. Phosphorus transfers from terrestrial to aquatic ecosystems. p. 171-200. In H. Tiessen (ed.) Phosphorus cycling in terrestrial and aquatic ecosystems: A global perspective. John Wiley, New York.

Sharpley, A.N., and S. Rekolainen. 1997. Phosphorus in agriculture and its environmental implications. p. 1-55. In H. Tunney (ed.) Phosphorus loss from soil to water. CAB International, Wallingford, UK

Shreve, B.R., P.A. Moore, D.M. Miller, T.C. Daniel, and D.R. Edwards. 1996. Long term phosphorus mobility in soils receiving poultry litter treated with aluminum, calcium, and iron amendments. Commun. Soil Sci. Plant Anal. 27:2493-2510.

Sibbesen, E. 1978. An investigation of anion exchange resin method for soil phosphorus extraction. Plant Soil 50:305-321.
Sibbesen, E., and A. Runge-Metzger. 1995. Phosphorus balance in European agriculture. p. 43-58. In H. Tiessen (ed.) Phosphorus cycling in terrestrial and aquatic ecosystems: Global perspective. John Wiley, New York.

Sibbesen, E., and A.N. Sharpley. 1997. Setting and justifying upper critical limits for phosphorus in soils. p. 151-176. In H. Tunney et al. (ed.) Phosphorus loss from soil to water. CAB International, Wallingford, UK.

Sinaj, S., E. Frossard, and J.C. Fardeau. 1997. Isotopically exchangeable phosphate in size fractionated and unfractionated soils. Soil Sci. Soc. Am. J. 61:1413-1417.

Sinaj, S., E. Frossard, and J.L. Morel. 1992. Phosphate availability in Albanian soils. p. 306-307. In A. Scaife (ed.) Proc. of the 2nd Congr. of the European Society of Agronomy, Warwick, UK. 23-28 Aug. 1992. European Society for Agronomy, HRI, Wellesbourne, UK.

Sinaj, S., F. Mächler, E. Frossard, C. Faisse, A. Oberson, and C. Morel. 1998. Interferences of colloidal particles in the determination of orthophosphate concentration in soil water extracts. Commun. Soil Sci. Plant Anal. 29:1091-1105.

St. Arnaud, R.J., J.W.B. Stewart, and E. Frossard. 1988. Application of the "Pedogenic Index" to soil fertility studies, Saskatchewan. Geoderma 43:21-32.

Stewart, J.W.B., and R.B. McKercher. 1982. Phosphorus cycle. p. 221-238. In R.G. Burns and J.H. Slater (ed.) Experimental microbial ecology. Blackwell Scientific Publ., Oxford, UK.

Stewart, J.W.B., and H. Tiessen. 1987. Dynamics of soil organic phosphorus. Biogeogem. 4:41-60.

Stout, W.L., A.N. Sharpley, and H. Pionke. 1998. Reducing soil phosphorus solubility with coal combustion by-products. J. Environ. Qual. 27:111-118.

Syers, J.K., and D. Curtin. 1989. Inorganic reactions controlling phosphorus cycling. p. 17-29. In H. Tiessen (ed.) Phosphorus cycles in terrestrial and aquatic ecosystems (Regional Workshop 1: Europe). SCOPE/UNEP Proceedings, Univ, of Saskatchewan, SK, Canada. 1-6 May 1988. Czerniejewo Poland, Saskatchewan Inst. of Pedology, Univ. of Saskatchewan, SK, Canada.

Tiessen, H., J.W.B. Stewart, and D.W. Anderson. 1994a. Determinants of resilience in soil nutrient dynamics. p. 157-170. In D.J. Greenland and I. Szabolcs (ed.) Soil resilience and sustainable land use. CAB International, Wallingford, UK.

Tiessen, H., J.W.B. Stewart, and A. Oberson. 1994b. Innovative soil phosphorus availability indices: Assessing organic phosphorus. p. 143-162. In J.H. Havlin and J.S. Jacobsen (ed.) Soil testing: Prospects for improving nutrient recommendations. SSSA Spec. Publ. 40. SSSA, Madison, WI.

Torrent, J. 1997. Interactions between phosphate and iron oxide. Adv. Geoecol. 30:321-344.

Tran, T.S., R.R. Simard, and J.C. Fardeau. 1992. A comparison of four resin extractions and 32P isotopic exchange for the assessment of plant available P. Can. J. Soil Sci. 72:281-294.

Tunney, H., A. Breeuwsma, P.J.A. Withers, and P.A.I. Ehlert. 1997. Phosphorus fertilizer strategies: Present and future. p. 177-204. In H. Tunney et al. (ed.) Phosphorus loss from soil to water. CAB International, Wallingford, UK.

van der Molen, D.T., A. Breeuwsma, and P.C.M. Boers. 1998. Agricultural nutrient losses to surface water in the Netherlands: Impact, strategies, and perspectives. J. Environ. Qual. 27:4-11.

van der Pauw, F. 1971. An effective water extraction method for determination of plant-available soil phosphorus. Plant Soil 34: $467-481$.

van der Zee, S.E.A.T.M., L.G.J. Fokkink, and W.H. van Riemsdijk. 1987. A new technique for assessment of reversibly adsorbed phosphate. Soil Sci. Soc. Am. J. 51:599-604.

Walker, T.W., and J.K. Syers. 1976. The fate of phosphorus during pedogenesis. Geoderma 15:1-19.

Yanai, R.D. 1992. Phosphorus budget of a 70-year-old northern hardwood forest. Biogeochem. 17:1-22.

Zaccheo, P., P. Genevini, and D. Ambrosini. 1997. The role of manure in the management of phosphorus resources at an Italian croplivestock production farm. Agric. Ecosyst. Environ. 66:231-239.

Zoysa, A.K.N., P. Loganathan, and M.J. Hedley. 1997. A technique for studying rhizosphere processes in tree crops: Soil phosphorus depletion around camellia (Camellia japonica L.) roots. Plant Soil 190:253-265. 